Navigation Physics 1(1)(2019)
Navigation Physics
Journal of Physics Education

\title{
Pemanfaatan Media Pembelajaran Phet Simulation dalam Eksperimen Fisika
}

\author{
Dasmo $^{1}$, Yoga Budi Bhakti ${ }^{2}$ dan Napis ${ }^{3}$ \\ 1,2,3 Universitas Indraprasta PGRI \\ *E-mail: bhaktiyoga.budi@gmail.com
}

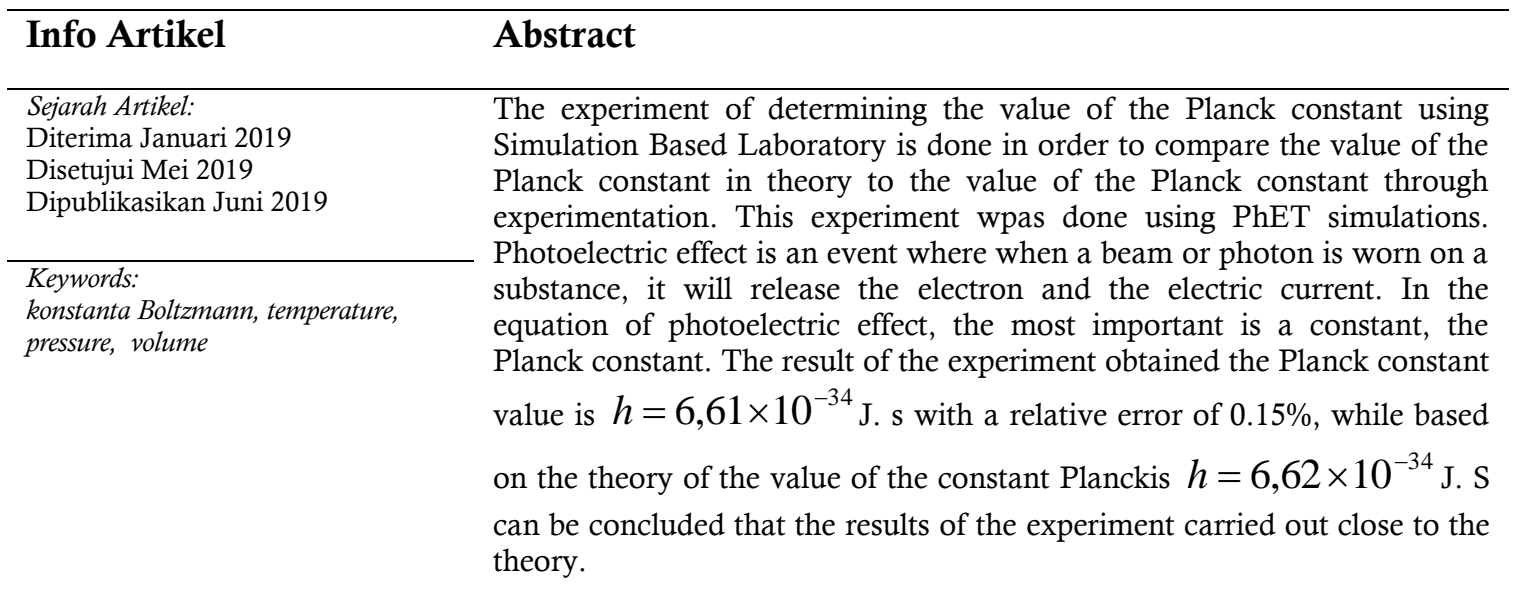

How to Cite: Dasmo, Bhakti, Y. B. \& Napis. (2019). Pemanfaatan Media Pembelajaran Phet Simulation dalam Eksperimen Fisika, Navigation Physics, 1 (1), 18-21.

\section{PENDAHULUAN}

Pada tahun 1887 Heinrich Hertz melakukan sebuah eksperimen penyinaran pelat katoda dengan aneka cahaya, menghasilkan sebuah fakta bahwa adanya elektron-elektron yang dipancarkan oleh pelat katoda tersebut. Eksperimen ini kemudian dikenal sebagai efek fotolistrik. Dalam fisika klasik hal ini cukup membingungkan para fisikawan pada saat itu, karena banyak hal yang tidak bisa dijelaskan secara klasik. Max Planck kemudian mengemukakan bahwa sebuah atom yang bergetar hanya dapat menyerap atau memancarkan energi kembali dalam bentuk buntelan-buntelan energi yang disebut kuanta (Krane, 1992 : 94). Dengan berbagai perhitungan yang dilakukan para fisikawan modern dulu akhirnya konstanta planck ditentukan sebesar J.s.

Banyak cara atau metode yang digunakan untuk membuktikan kebenaran konstanta planck ini, salah satunya adalah menggunakan metode Simulation Based Laboratory (SBL), dengan simulasi ini maka dapat dengan mudah membuktikan konstanta planck. Physics Education Technology (PhET) adalah salah satu alat yang menggunakan metode SBL, sebuah software terbitan University of Colorado ini sangat membantu kita dengan berbagai simulasi yang ada di dalamnya.

Apabila suatu cahaya mengenai permukaan zat atau bahan, maka elektron-elektron pada zat atau bahan tadi akan terlepaskan apabila beberapa syarat tertentu dapat terpenuhi. Sebuah foton dengan energi $h f$ bertumbukan dengan elektron di permukaan zat, sehingga foton memindahkan semua energinya ke elektron, dan kerja minimum yang dibutuhkan untuk melapaskan elektron dari permukaan adalah $W_{\text {min }}$ (Bueche, 1989 : 325). Maka energi kinetik maksimum yang diperoleh elektron yang terbebas dari permukaan ialah 


$$
\frac{1}{2} m v_{\text {maks }}^{2}=h f-W_{\text {min }}
$$

energi kinetik foton dinyatakan sebagai

$$
\begin{aligned}
& E_{k}=h v-\phi \\
& E_{k}=h \frac{c}{\lambda} \\
& V_{s}=\frac{h v}{e}-\frac{\phi}{e} \\
& V_{s}=\frac{h c}{e} \frac{1}{\lambda}-\frac{\phi}{e}
\end{aligned}
$$

dengan $V_{s}$ adalah tengangan penghenti (stoping potential).

Robert Millikan memberikan bukti yang lebih meyakinkan tentang kesesuaiannya dengan konstanta planck dalam serangkaian percobaan yang dilakukan pada tahun 1915. Salah satu percobaannya adalah pada logam natrium, diperoleh bahwa kemiringan grafik hasil percobaan $h / e$. Hal ini tidak lain adalah rajahan persamaan, diperoleh tetapan planck

$$
h=6,57 \times 10^{-34} \mathrm{~J} . \mathrm{s}
$$

Nilai ini sangat sesuai dengan nilai dari pengukuran tetapan Stefan-Boltzman. Kesesuaian yang baik ini memperlihatkan bahwa tetapan Planck mempunyai arti penting dan dipandang sebagai salah satu tetapan alam, dan telah diukur dengan ketelitian yang sangat tinggi dalam berbagai percobaan. Nilai yang sekarang diterima adalah

$$
h=6,62618 \times 10^{-34} \mathrm{~J} . \mathrm{s}
$$

\section{METODE PENELITIAN}

Dalam penentuan konstanta Planck dengan metode simulasi, dibutuhkan software animasi tentang fisika, dalam hal ini digunakan PhET (Physics Education Technology). Aktifkan perangkat lunak PhET, kemudian pilih simulasi efek fotolistrik, seperti gambar 1.

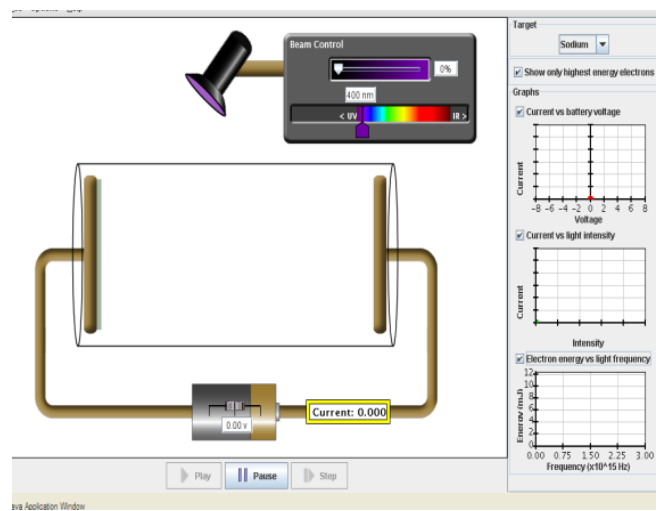

Gambar 1. Tampilan simulasi efek

Metode analisis data yaitu menggunakan persamaan 5 sehingga diperoleh :

$V_{s}=\frac{h c}{e} \frac{1}{\lambda}$

dengan menggunakan analisis regresi, maka :

$$
y=a x+b
$$


dimana $\mathrm{y}=\mathrm{V}_{\mathrm{s}}$, dan $x=\frac{1}{\lambda}$

maka diperoleh gradien

$$
a=\frac{h c}{e}
$$

Sehingga diperoleh persamaan konstanta planck

$$
h=\frac{a e}{c}
$$

\section{HASIL DAN PEMBAHASAN}

Berdasarkan eksperimen yang telah dilakukan, diperoleh data sebagai berikut :

Tabel 1. Data hasil eksperimen

\begin{tabular}{llll}
\hline Panjang & \multicolumn{1}{c}{$\frac{1}{c} V_{\mathrm{s}}$ (volt) } \\
\cline { 3 - 4 } Gelombang $(\mathrm{nm})$ & \multicolumn{1}{c}{$\lambda$} & $\begin{array}{c}\text { Intensitas I } \\
\mathbf{( 4 0 \% )}\end{array}$ & $\begin{array}{c}\text { Intensitas } \\
\text { II (80\%) }\end{array}$ \\
$\mathbf{2 0 0}$ & 0.005 & 4.1 & 4.1 \\
$\mathbf{2 5 0}$ & 0.004 & 2.8 & 2.8 \\
$\mathbf{3 0 0}$ & 0.00333333 & 2.1 & 2.1 \\
$\mathbf{3 5 0}$ & 0.00285714 & 1.4 & 1.4 \\
$\mathbf{4 0 0}$ & 0.0025 & 1 & 1 \\
\hline
\end{tabular}

Dari data eksperimen pada tabel 1, dapat diketahui bahwa semakin besar panjang gelombangnya maka intensitasnya semakin kecil. Sehingga panjang gelombang berbanding terbalik dengan intensitas cahaya. Dengan melakukan fitting data diperoleh grafik seperti dibawah ini.

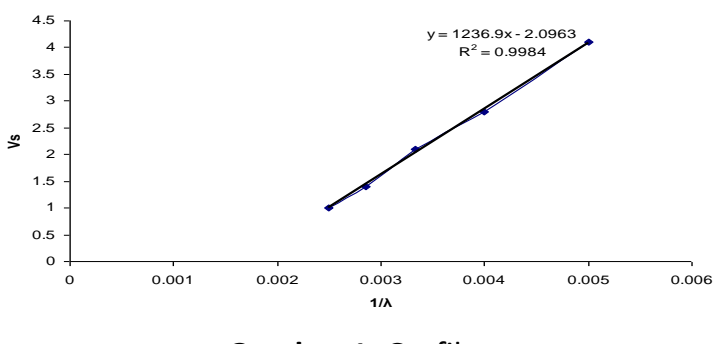

Grafik 1. Hubungan Vs dan 1/

Dengan menggunakan analisis regresi linier pada grafik 1 , maka dapat diperoleh nilai gradien

$a=1236,9 \mathrm{~nm}=1236,9 \times 10^{-9} \mathrm{~m}$

dengan menggunakan persamaan (11) maka dapat diperoleh nilai konstanta Planck sebesar $h=6,61 \times 10^{-34}$ J.s

Nilai konstanta Planck ini mendekati nilai secara teori dengan error relatif sebesar 0,15\%. Hal ini, disebabkan karena adanya pengaruh suhu ruangan saat dilakukan eksperimen yang terlalu dingin sehingga menyebabkan partikel-partikel dalam erlemayer tidak bergerak secara acak, jarak antar partikel menjadi lebih rapat maka tekanan gas menjadi lebih kecil dibandingkan dengan suhu normal. 


\section{PENUTUP}

Percobaan dengan menggunakan metode simulasi PhET merupakan cara yang amat mudah dalam pembelajaran fisika. Tidak perlu direpotkan dengan persiapan-persiapan alat percobaan yang belum tentu hasilnya juga valid. Dengan metode ini terbukti bahwa tetapan Planck secara eksperimen mendekati dengan nilai teori yaitu diperoleh sebesar $h=6,61 \times 10^{-34} \mathrm{~J} . \mathrm{s}$

\section{DAFTAR PUSTAKA}

Bueche, F.J.1989. Teori dan soal Fisika. Jakarta : Penerbit Erlangga.

Giancoli, Douglas C. 2001. Fisika Jilid 1. Erlangga : Jakarta.

Halliday, David., Robert Resnick, 1985. Fisika Jilid 1, Ed.3, Erlangga, Jakarta.

Krane, K. 1992. Fisika Modern. Jakarta : Penerbit Universitas Indonesia (UI Press).

Tipler, Paul A. 1998. Fisika untuk Sains dan Teknik Jilid 1. Erlangga : Jakarta. 